\title{
Calcium supplementation in osteoporosis: useful or harmful?
}

\author{
lacopo Chiodini, ${ }^{1,2}$ and Mark J Bolland ${ }^{3}$ \\ ${ }^{1}$ Department of Medical Sciences and Community Health, University of Milan, Milan, Italy, ${ }^{2}$ Unit of Endocrinology, \\ Fondazione IRCCS Cà Granda, Milan, Italy, and ${ }^{3}$ Department of Medicine, University of Auckland, Auckland, \\ New Zealand
}

Correspondence should be addressed to I Chiodini

Email

iacopo.chiodini@unimi.it

\begin{abstract}
Osteoporosis and fragility fractures are important social and economic problems worldwide and are due to both the loss of bone mineral density and sarcopenia. Indeed, fragility fractures are associated with increased disability, morbidity and mortality. It is known that a normal calcium balance together with a normal vitamin D status is important for maintaining well-balanced bone metabolism, and for many years, calcium and vitamin D have been considered crucial in the prevention and treatment of osteoporosis. However, recently, the usefulness of calcium supplementation (alone or with concomitant vitamin D) has been questioned, since some studies reported only weak efficacy of these supplementations in reducing fragility fracture risk. On the other hand, besides the gastrointestinal side effects of calcium supplements and the risk of kidney stones related to use of co-administered calcium and vitamin D supplements, other recent data suggested potential adverse cardiovascular effects from calcium supplementation. This debate article is focused on the evidence regarding both the possible usefulness for bone health and the potential harmful effects of calcium and/or calcium with vitamin D supplementation.

\section{Introduction}

The burden of osteoporotic fractures is an important social and economic problem worldwide and both the loss of bone mineral density (BMD) and the reduction of muscle function are major causes of these healthdefining events $(1,2,3)$. Fragility fractures are associated with important disability, increased morbidity and a $20 \%$ increased mortality (2).

For many years, a normal calcium balance together with normal vitamin D status has been considered crucial for maintaining well-balanced bone metabolism and in the prevention and treatment of osteoporosis $(4,5)$. However, in recent years, the usefulness of calcium supplementation (alone and with concomitant vitamin D supplementation) has been questioned, since some studies reported only weak efficacy of these supplementations in reducing fragility fracture risk $(6,7,8)$. Concomitantly, besides the known gastrointestinal side effects of calcium supplements and the risk of kidney stones related to use of co-administered calcium and vitamin D supplements, other evidence suggested potential adverse cardiovascular effects from calcium supplementation $(9,10,11)$.

The aim of this debate article is to focus on the evidence regarding both the possible usefulness for bone health and the potential harmful effects of calcium and/ or calcium with vitamin D supplementation.

\section{Calcium supplementation in osteoporosis: useful (Iacopo Chiodini)}

\section{Calcium intake}

The concept of the usefulness of calcium supplementation for bone health is based on the fact that in humans, as

Published by Bioscientifica Ltd. 
in other mammals, the bone-parathyroid-kidney-ileum axis is finely tuned for the maintenance of physiological calcium and phosphorous levels and the renewal of bone tissue (12). The fact that at bone level the type 1 collagen matrix is strengthened with the apposition of calcium hydroxyapatite crystals supports the idea that an adequate calcium status is crucial for bone health (13). The dietary calcium intake may be adequate in most individuals, but, there is evidence that in subjects with inadequate calcium and vitamin D intake, the supplementation strategies are useful for preventing osteoporosis-related fragility fractures $(14,15)$. Indeed, in the presence of inadequate calcium intake and/or vitamin D production, the latter being fundamental for a proper intestinal calcium absorption, the incipient hypocalcemia leads to a secondary hyperparathyroidism, increased bone turnover, bone loss and increased facture risk (16). Interestingly, in turn, vitamin D levels appear to be dependent on calcium intake at or above recommended levels (17).

Moreover, calcium is fundamental even for the muscle physiology and in the skeletal-muscle interaction. Indeed, within the muscle cells, the contraction and relaxation of myosin fibers and the glycolytic and mitochondrial metabolisms have been suggested to be regulated by calcium levels $(18,19)$. Therefore, the adequate calcium status is important for both bone and muscle.

These considerations explain the high number of studies investigating both the calcium intake in the different populations and the usefulness of calcium and vitamin D supplementation strategies for preventing fragility fractures. However, it is important to note that the dietary calcium intake is very different among the various populations around the world, and, therefore, the calcium supplements may be of importance for bone health in some countries but much less in others (20). For example, in a study in the United States, less than one-third of women aged 9-71 years had an adequate intake of calcium from their diet alone and even among supplement users ( $75 \%$ of cases) less than $50 \%$ of subjects achieved the recommended calcium intake (21). In a study on about 370 Italian postmenopausal women, the mean daily calcium intake was about $600 \mathrm{mg} /$ day and the $20 \%$ of subjects were taking less than $300 \mathrm{mg}$ /day of calcium from dairy products (22). In keeping, in a more recent study in a population of Italian patients with type 1 diabetes, the $50 \%$ of men and $27 \%$ of women showed a calcium intake below the threshold recommended for the Italian general population (23). At variance, for example, in two studies on non-osteoporotic men in New Zealand conducted by the group of the coauthor of the present article, the mean calcium intake was about $800 \mathrm{mg} /$ day $(24,25)$. Further complicating matters, the national recommendations on calcium intake for different ages and genders vary worldwide (20), being for example between 1000 and $1300 \mathrm{mg} /$ day in those from the US National Institutes of Health (26) and between 700 and $1000 \mathrm{mg} /$ day in those from the National Osteoporosis Society (27). In general, even if these latter recommendations defines $400 \mathrm{mg} /$ day as the lowest amount of calcium required to maintain a healthy skeleton (28), the adequate calcium supplementation for bone health is still a matter of debate, and it is influenced by several factors, such as age and vitamin D levels (17). It is clear, therefore, that the different calcium intake among the different populations may be an important confounding factor in interpreting the results of the studies on the effect of calcium supplements on bone, since data from randomized controlled trials were not able to be adjusted for baseline personal calcium intake without making subgroups analyses with the consequent loss of the randomized design (6).

Other important confounding factors in the interpretation of these studies are that the different lifestyle and social habits may have influenced the outcomes. For example, it is possible that calcium and other supplements are used by patients with very poor health, with the hope of improving daily activities and quality of life. On the other hand, the use of calcium supplements may be frequent among the very healthy subjects with lifestyle and other dietary habits associated with low morbidity and mortality (6). It is possible, therefore, that the small effect of calcium supplements that can be appreciated at the population level, is, in fact, derived from an important effect in a small number of subjects.

\section{Calcium supplements and bone mineral density (BMD)}

The importance of the calcium intake during adolescence has been evidenced by a recent double-blind randomized controlled trial on 220 Chinese teens showing that, after two years of low, medium or high calcium intake levels, the BMD increases in female adolescents who ingested more calcium $(28,29)$. In keeping, some data suggest that BMD is reduced and the fracture is increased in adult women who drunk less milk during childhood and adolescence (30).

Even in adults, BMD has been suggested to be possibly influenced by calcium intake. Indeed, in the Women's Health Initiative (WHI) study on more than 36000 
postmenopausal women BMD at hip was slightly higher in the calcium plus vitamin D group than in the placebo group (31). In a more recent study on about 7000 subjects older than 50 years of age, a calcium intake below $400 \mathrm{mg}$ / day was associated with lower BMD and femoral cortical thickness, while a calcium intake above $1200 \mathrm{mg}$ /day was positively correlated with BMD (32). In keeping, the metaanalysis from Shea and coauthors found that calcium was more effective than placebo in reducing the rates of bone loss after at least two years of treatment, with a difference in percentage change from baseline of $1.7 \%$ and $1.6 \%$ for spinal and hip BMD, respectively (33). Another five-year randomized controlled trial on about 1450 elderly women reported an improvement in ultrasonographic parameters related to bone density in women with an adequate $(>80 \%)$ compliance to the supplements, suggesting that adherence to treatment is crucial for the therapy to be effective (34). Similarly, a recent meta-analysis of nine studies showed that supplementation with calcium plus vitamin $\mathrm{D}$, has a small-to-moderate effect on spinal and femoral BMD in healthy males (35). Partially in discordance, in the meta-analysis of Tai and coauthors (including 59 studies) increasing calcium intake from dietary sources increased femoral BMD by $0.6-1.0$ and femoral and spinal BMD by $0.7-1.8 \%$ at two years, but the increase in BMD at later time points was similar to the increase at one year (36).

Overall, these data suggest that calcium supplement have positive effects on BMD, which is probably more important in subjects with adequate compliance to the supplements and with baseline lower dietary calcium intake (8).

\section{Calcium, vitamin D and risk of falling}

An important issue that might support the usefulness of calcium supplementation (with or without vitamin D), at least in patients with low calcium intake, is the possible positive role of these supplements on muscle function. This hypothesis has been tested in several randomized clinical trials and several meta-analyses that tried to summarize these results. Overall, the majority of these studies showed that a steady vitamin D supplementation reduced the risk of falling in particular in patients with vitamin $\mathrm{D}$ deficiency and who reach adequate vitamin $\mathrm{D}$ levels $(37,38,39,40,41,42)$, even though some authors were not able to find the same conclusions (43).

The possible adjunctive effect of calcium to vitamin D on the risk of falling, however, is still not clear, probably due to the fact that these effects may be concealed in patients with normal calcium intake, which has not been estimated in the majority of studies. This idea is reinforced by the finding that alfacalcidol reduces the number of fallers in a community-dwelling elderly population with a minimum calcium intake of more than $500 \mathrm{mg}$ daily (44). In general, the available studies failed to demonstrate an adjunctive effect of calcium (41, 42, 43, 45, 46), even though two studies found that the vitamin $\mathrm{D}$ effect in reducing the risk of falls was stronger when calcium supplements were co-administered $(38,46)$.

However, some evidences suggest a relation between low calcium intake and low muscle mass (47), since a decreased calcium absorption and an altered calcium homeostasis are associated with muscle weakness in the aged individuals $(48,49)$. Therefore, although we have low evidence for an effect of calcium supplementation in addition to vitamin $\mathrm{D}$ for reducing the risk of falling, in patients with osteoporosis estimating the calcium intake is mandatory, since, besides secondary hyperparathyroidism, an incipient hypocalcemia leads muscle-related symptoms, than can ameliorate with calcium supplementation. Overall, it is reasonable to consider calcium supplements in the prevention and treatment of sarcopenia in older adults with a low calcium intake (3).

\section{Calcium supplements and risk of fracture}

Since the vitamin D status is crucial for calcium absorption, the efficacy of calcium supplement alone may be different from that of calcium with concomitant vitamin D supplements. In the meta-analysis of Tang and coauthors, which included more than 52000 patients, a statistically significant reduction of fragility hip fracture risk was demonstrated for calcium with vitamin D supplements (relative risk, RR 0.87) but not with calcium alone supplements (50). In keeping, a subsequent meta-analysis, having the risk of hip fracture as outcome, was not able to find any protective effect of calcium alone supplements, which were even associated with an increased number of events (51). At variance, in a more recent meta-analysis including 13 studies, the coauthor of the present article found that the calcium supplementation alone was associated with a $15 \%$ reduction in risk of any fracture but not of hip, vertebral or forearm fractures (52).

Data on the fracture risk reduction related to the use of calcium with vitamin D supplements are more consistent. In 2010, the Group DVDIPAoRT published an individual data meta-analysis including 68500 patients from 7 randomized controlled trials (with a follow-up between 18 and 85 months, 2 studies being performed in 
institutionalized subjects) showing a statistical significant reduction in all fractures (hazard ratio, HR 0.92) and hip fractures (HR 0.83) for the calcium with concomitant vitamin D supplements (53). Interestingly, since patients enrolled in the trials assessing the efficacy of calcium with vitamin D were all community dwelling, this study suggests that this type of supplementation is efficacious even in the free-living setting. Similarly, in the trial data, meta-analysis performed by the US National Osteoporosis Foundation (NOF), which included 8 studies (about 31 000 subjects), a $15 \%$ reduction of overall fracture risk and a $30 \%$ reduction of hip fracture risk was found (7). These data are similar to those previously published in the meta-analysis of Tang and coauthors, who found a statistically significant reduction of all fractures (RR 0.99) and hip fractures (0.87) in participants taking calcium with concomitant vitamin D supplements (50).

Even in the meta-analysis performed by the coauthor of this article including 26 trials (more than 69000 subjects) a risk reduction for all and hip fractures (RR 0.92 and 0.84 , respectively) with combined calcium and vitamin D administration was found. However, when the analysis was confined to the four trials at low risk of bias, as defined by the authors using the Cochrane guidance, the effect on the risk of fracture at any site was no longer present (42). However, even though these studies were a low risk of bias, they might be intrinsically biased. Indeed, since these studies have been designed on the intention-to-treat principle, the optimal adherence to the medicaments prescribed was not certain, potentially leading to confounding results $(31,34,54,55)$. For example, in the study by Prince and coauthors, even though in the intention-to-treat analysis calcium supplementation did not significantly reduced the fracture risk, among the 830 patients $(56.8 \%)$ who took $80 \%$ or more of their tablets (calcium or placebo) per year, patients taking calcium had a statistical significant reduction of the fracture incidence (HR 0.66) compared with subjects taking placebo (34). In the RECORD study, performed on 5292 already fractured elderly people (85\% women), who were randomly assigned to oral vitamin D or calcium with vitamin D or calcium alone or placebo, the authors did not find difference in the risk fracture in any site, but it must be observed that in this study, there was about $10 \%$ reduced compliance in patients taking tablets containing calcium as compared with those taking vitamin D or placebo, partly because of gastrointestinal symptoms (54). Finally, in the WHI study, the intention-totreat analysis indicated that participants receiving calcium plus vitamin D supplementation had a not statistically significant HR of 0.88 for hip fracture, which, however was reduced to 0.71 and became statistically significant after censoring data from women not adherent to the study medication (31). The deviation from an intentionto-treat analysis may be an exceptionable approach, but it might be justified for establishing the efficacy (a biological effect) of these supplements, considering the often poor compliance with calcium supplementation. Interestingly, the several adjustment analyses performed in the NOF meta-analysis for adjusting for the possible unbalanced randomization derived from deviating from the intentionto-treat analysis confirmed the protective effect of calcium and concomitant vitamin D supplementation on fracture risk $(7,56,57)$.

Some other considerations should be done about the issue of the correct intake of the prescribed supplements during the study protocols. For example, a possible confounding factor in the interpretation of these studies is the possibility that participants personally used calcium and vitamin D supplements. Indeed, a reanalysis of the WHI trial, in which study subjects were permitted personal use of calcium and vitamin D (31), showed that after stratifying by personal use of these supplements, the fracture reduction with calcium and vitamin D supplementation was no longer evident (58). However, again, as the randomization procedure was not designed to ensure balancing of patients according to this criterion, this stratification transformed this randomized controlled trial in an observational study, thus reducing its strength (6). Anyway, the explanation of these results is quite intuitive, as the efficacy of interventions for threshold nutrients cannot be established in individuals who are already sufficient (59). At the opposite, the persistence of low calcium intake even in patients included in the treatment-arm of the randomized controlled trials, due to low or sub-optimal adherence to the supplements prescribed, is an important issue, since treatments cannot work if they are not taken. This problem may be less important in studies performed in institutions, since in these latter, the administration of supplements may be more controlled. Therefore, the institution-settled studies may give more information about the efficacy of these supplements and some evidence seems to support this theory. First of all, one of the most clear fracture risk reduction with calcium and vitamin D supplements was found in the milestone study by Chapuy and coauthors, which has been performed in nursing and/or residential homes (60), while the fact that the RECORD study has been performed in a community setting may account for the completely negative results (54). Secondly, in the meta-analysis performed by the coauthor of this article, 
the hip fracture reduction with calcium and vitamin D supplementation was statistically significant when considering the trials performed on institutionalized patients but not when considering those including community-dwelling participants (52). Furthermore, even in the meta-analysis by Tang and coauthors, the calcium and vitamin $\mathrm{D}$ supplementation reduced the overall risk of fractures more in institutionalized patients than in community-dwelling ones, even if the important difference in the sample size of the two groups (49 233 vs 3392 individuals) may have introduced an important selection bias (50). In general, the community-based clinical trials, in which compliance was moderate or less, have often been negative, whereas studies in institutionalized patients, in whom medication administration was supervised, often demonstrated significant benefits (61).

Finally, a very recent meta-analysis of 33 randomized trials involving more than 51000 community-dwelling older adult participants found no significant association of combined calcium and vitamin D with hip, non-vertebral or total fractures compared with placebo (62). Even though the authors performed subgroup analyses showing that these results were generally consistent regardless of serum 25-hydroxyvitamin D concentration, dietary calcium and other confounders, again the community-dwelling setting may have concealed the effectiveness of the supplements. In fact, the data showed a trend (even if not statistically significant) for a reduction of hip, non-vertebral, vertebral and total fracture in individuals taking calcium with concomitant vitamin supplements. Moreover, the risk of hip and non-vertebral fractures tended to be lower in the individuals with vitamin D levels above $20 \mathrm{ng} / \mathrm{mL}$. Therefore, considering that the threshold of $20 \mathrm{ng} / \mathrm{mL}$ for vitamin D levels may be too low to ensure an adequate vitamin D status (63), it is not possible to exclude that the lack of effectiveness found in this meta-analysis may be due also to the lack of a normal vitamin $\mathrm{D}$ status in a significant part of the included individuals.

In keeping with this latter consideration, it must be observed that all available bone-active drugs are licensed in the context of an adequate calcium and vitamin $\mathrm{D}$ status, since the registration trials have been performed on patients always supplemented with calcium and vitamin D $(64,65)$. It is important to remind that the effect of the bone-active drugs in the absence of a concomitant calcium and vitamin D is substantially unknown. On the other hand, in the 'real life', the incidence of fractures during treatment with antiresorptive agents is considerably higher than that observed in randomized clinical trials and the inadequate compliance to antiresorptives or to supplementation of calcium and vitamin D are similarly important in determining this poor response (66). Again, since the dietary calcium intake is difficult to be estimated (67) and the vitamin D deficiency is extremely frequent (68) but not easily predictable without measuring vitamin D levels (69), in the clinical routine of the 'real life' the administration of supplements may be a simple way to ensure an adequate intake of calcium and vitamin D (7).

\section{Conclusions}

In our opinion, the present evidence suggests that calcium with concomitant vitamin D supplementation, but not calcium alone, leads to an increase in BMD and to a reduction of the risk of total by $15 \%$ and of hip fractures by $30 \%$. The entity of the hip fracture risk reduction obtained using calcium plus vitamin D supplements appears to be similar to that of the myocardial infarction risk obtained using statins, drugs that are widely considered to be effective (70). However, this does not justify a populationlevel intervention with statins, which are prescribed on the basis of the cardiovascular risk profile of the individual patient. Similarly, calcium supplements should not be suggested in patients with a normal calcium intake. On the other hand, in patients with an estimated low calcium intake and in those treated with bone-active drugs we should strongly suggest to increase the dietary calcium intake. In the impossibility to obtain a correct calcium intake through diet, calcium with concomitant vitamin D supplements should be given as, in this setting, they have to be considered an effective therapy for reducing the fragility fracture risk (71). This idea is also reinforced by the fact that the reported cardiovascular risk due to calcium supplementation is yet to be demonstrated and that studies that have evaluated the influence of dietary calcium intake did not show increase in the cardiovascular risk (28).

Therefore, the debated issue of the use of calcium supplements is perhaps more simple to resolve than expected. As any other dietary integration, the calcium supplements should be given in patients with insufficient calcium intake, particularly if osteoporotic and taking bone-active drugs.

\section{Calcium supplementation in osteoporosis: not useful (Mark Bolland)}

For the last few decades many experts, committees and specialist societies have recommended calcium intake 
targets for older women and men well above the average population dietary intakes. The most practical way of achieving these targets is to take a calcium supplement. In many western countries, these recommendations have been widely followed, so that the majority of older people take calcium supplements (21, 72, 73, 74). However, in the last 15 years, evidence has emerged that the risk-benefit profile of calcium supplements is not favorable for most people. In this review, I will make the case that widespread calcium supplementation is unnecessary because any small benefits in preventing fractures are outweighed by the common occurrence of mild side effects that lead to stopping the supplements and the less common occurrence of more serious side effects. I will begin by briefly reviewing the history of calcium intake recommendations then discuss the current evidence for benefits and harms of calcium supplements.

\section{Brief history of calcium intake recommendations}

Since Albright introduced the term postmenopausal osteoporosis in 1940, the role of calcium intake in the pathogenesis and treatment of osteoporosis has been investigated and debated. Albright and colleagues reported that estrogen reduced urine calcium excretion in postmenopausal women, creating a positive calcium balance $(75,76)$. However, they concluded that this was only secondary to the mechanism of action of estrogen and proposed that calcium and vitamin D deficiency could cause osteomalacia, but postmenopausal osteoporosis is caused by estrogen deficiency and not related to calcium intake $(75,76)$. Contemporaneous studies of populations with low calcium intakes did not report poor bone health, supporting this view $(77,78,79,80)$. Subsequently, many international and national bodies made recommendations about calcium intake for adults, with recommendations lowering from 1000 to $800 \mathrm{mg} /$ day in 1953 (81) to $400-500 \mathrm{mg} /$ day by 1974 (82).

Subsequently, views shifted based on new research and higher calcium intakes again were recommended.
Heaney and colleagues published a series of influential calcium balance studies, concluding that premenopausal women required $1000-1200 \mathrm{mg} /$ day and postmenopausal women $1500 \mathrm{mg} /$ day to maintain neutral calcium balance $(83,84)$. Small increases in bone density were reported in randomized controlled trials (RCTs) of calcium supplements with or without vitamin D $(85,86)$. Chapuy and colleagues reported that calcium and vitamin $\mathrm{D}$ reduced hip and total fractures by about $30-40 \%$ over 18 months in a very influential large placebo-controlled RCT conducted in frail elderly women living in residential care in France (60). Based on these results, the case for calcium supplementation seemed compelling, at least for older postmenopausal women. Therefore, many major guidelines recommended calcium supplements in doses $\geq 1000 \mathrm{mg}$ /day for the treatment and prevention of osteoporosis, and the majority of older people in many western countries took calcium supplements $(21,72,73$, 74). Despite the apparent consensus, important questions remained about the existing research $(87,88)$ and other issues related to calcium supplement use (Table 1). Many of these questions were addressed in later clinical studies.

\section{Later research}

In a large series of calcium balance studies, Hunt and Johnson reported that neutral calcium balance occurred at a much lower calcium intake $(741 \mathrm{mg} /$ day $)$ than reported by Heaney and colleagues, and also was not altered by age or sex (89). Although longer than previous studies (each balance study had a minimum duration of 16 days); nevertheless, these studies still may not be long enough for adaptation to a change in calcium intake. 50 years earlier, Malm reported that after an abrupt decrease in calcium intake, positive calcium balance was eventually restored, but it took many weeks to months before adaptation was complete (87).

Numerous RCTs studying the effect of calcium supplements or increasing calcium intake on bone density have now been reported. In 2015, we performed

Table 1 Outstanding questions about calcium supplements following publication of the 1993 trial by Chapuy and colleagues (60).

1. Do the results from the calcium balance studies conducted by Heaney and colleagues $(83,84)$ apply universally, particularly in countries with lower or higher long-term calcium intake?

2. Calcium supplements slowed down but did not prevent bone loss, and results from randomised controlled trials are inconsistent. Would these findings have long-term treatment implications?

3. Are the results of the Chapuy trial that was carried out in frail elderly women living in residential care in France generalizable beyond that population group?

4. Does calcium and vitamin D co-administration produce better results than either agent alone?

5. Calcium supplements are not very palatable and often cause gastrointestinal side effects. What implications would side effects have for long-term compliance and the risk-benefit profile? 
a systematic review identifying 59 such RCTs (36). Meta-analyses of these RCTs showed a number of important findings. Firstly, calcium supplements had similar effects on bone density to dietary sources of calcium. Secondly, increases in bone density were only small $(<2 \%)$ and oneoff, that is the increases in bone density were present at one year, and thereafter did not increase. Thirdly, the addition of vitamin D to calcium did not lead to additional benefits, and effects were also similar regardless of calcium dose or baseline calcium intake (36). An early RCT had specifically addressed the issue of effects of calcium supplementation on bone density by baseline calcium intake (90). In 103 postmenopausal women, the effects of $500 \mathrm{mg} /$ day of calcium supplements for two years on forearm bone mineral content and urinary calcium excretion were very similar in women with baseline calcium intakes of $<550$, 550-1150 and $>1150 \mathrm{mg} /$ day (90). Thus, later trials have not confirmed the reports of sustained important effects on bone density from early RCTs of calcium supplements or the view that there is a state of 'calcium deficiency' that can be rectified by supplementation.

Six RCTs of calcium supplements (with or without vitamin D) with fracture as a primary outcome reported their results between 2005 and 2010 (31, 34, 54, 55, 91, 92). All were carried out in community-dwelling individuals, and none reported a statistically significant reduction in fractures. When meta-analyzed together with all other available RCTs, there is only weak and inconsistent beneficial effects of calcium supplements on fracture, with no effect seen in the large double-blind placebo-controlled RCTs at lowest risk of bias (52). Numerous meta-analyses of RCTs of calcium with or without vitamin D with fracture as the outcome have been conducted, and their conclusions often differ even though they review largely the same group of studies. The differing conclusions seem mainly due to differences in trial selection, definition of the fracture outcomes and methods used in the meta-analysis (93). However, recent meta-analyses do consistently conclude that calcium supplements with or without vitamin $\mathrm{D}$ in community-dwelling individuals do not prevent hip or total fractures $(5,52,62,94)$. Likewise, in 44 cohort studies, the overwhelming majority reported no relationship between baseline intake of calcium, milk or dairy and fracture outcomes at any site (52). Taken together, there is no evidence currently of an association between calcium intake and fracture risk or that increasing calcium intake alters fracture risk in a meaningful way.

The clear exception is the RCT by Chapuy and colleagues (60), which demonstrated unequivocal benefits from co-administered calcium and vitamin D supplements and which the same investigators largely replicated in a smaller RCT in a similar population 10 years later (95). The results of these two trials are clear outliers from the results of RCTs of calcium and vitamin D in community-dwelling individuals and also from the results of RCTs of vitamin $\mathrm{D}$ in individuals in residential care $(42,94)$. The reason for these differences is not clear. One possible explanation is a high background rate of untreated osteomalacia in the populations studied by Chapuy and colleagues, which had a mean baseline 25-hydroxyvitamin D level of about $20 \mathrm{nmol} / \mathrm{L}$ in both RCTs, suggesting that a substantial proportion of participants had severe vitamin D deficiency. A reanalysis of the Chapuy trials by baseline 25-hydroxyvitamin D level might prove instructive. Another important issue is that these two RCTs are extremely influential in any meta-analysis. Whatever subgroup these two RCTs are placed in has reductions in fracture risk that are not consistent with results from subgroups without these trials (52). It seems clear that the results from these studies conducted in a very frail population with marked vitamin D deficiency are so influential in any meta-analysis that they should not be pooled with studies conducted in different patient groups. Recommending widespread use of calcium and vitamin D supplements for otherwise healthy community-dwelling older adults based upon meta-analyses heavily influenced by these RCTs in a unique population group is therefore inappropriate.

If taking calcium supplements did prevent a small number of fractures, there may be large benefits for a population if they were widely used, even though there would be no meaningful benefit for each individual user. In this situation, safety becomes an important consideration, because the small risk of a side-effect can translate into a large number of adverse events when there is widespread use of an agent in a population. The completion of the large RCTs of calcium supplements has clarified their side-effect profile. Calcium supplements are unpalatable to many and commonly cause minor gastrointestinal side effects such as constipation and dyspepsia (55). Frequently, these side effects cause the individual to stop the supplements, and their occurrence is sufficient to explain the poor long-term compliance of $40-60 \%$ reported in the large RCTs $(31,34,54,55)$. More significant side effects have been reported from 3 RCTs. In the Women's Health Initiative, there was a 17\% increased relative risk of kidney stones with calcium and vitamin D supplements (31). Prince and colleagues reported that calcium supplements increased the relative risk of acute gastrointestinal symptoms causing hospitalization by 
92\% (96). In our trial, calcium supplements increased the rate of the composite endpoint of myocardial infarction, stroke and sudden death (97), and the relative risk of hip fracture (55). Subsequent meta-analyses of RCTs of calcium monotherapy confirmed increases of hip fracture of about $50 \%(51,98)$, increases of myocardial infarction of about $30 \%$ and reported a possible increase in stroke of about $15-20 \%(9,10)$. Hypercalcemia has also been reported from the use of co-administered calcium and vitamin D supplements $(99,100)$. The table shows a comparison between the reduction in numbers of participants with fractures and the numbers of participants experiencing adverse events in the large RCTs (101). When adverse event data have been reported from large RCTs, in most cases, there are numerically more serious adverse events than fractures prevented (Table 2). For example, the number needed to harm to cause one vascular event (i.e. 178) is less than the number needed to treat to prevent one fracture (i.e. 302) in community-dwelling individuals (9).

One reason sometimes given for recommending the use of calcium and vitamin $\mathrm{D}$ is that all major trials of osteoporosis agents have used calcium and vitamin D supplements; therefore, their use is necessary when osteoporosis agents are prescribed (and is safe). However, this view does not withstand scrutiny. RCTs comparing co-administration of an antiresorptive plus calcium and vitamin D with placebo plus calcium and vitamin D do not allow conclusions to be drawn about either the necessity of calcium and vitamin D or its safety. No large trial with fracture outcomes has compared an effective osteoporosis treatment (e.g. a bisphosphonate) co-prescribed with calcium and vitamin D to the osteoporosis treatment alone. However, trials of osteoporosis treatments without calcium and vitamin $\mathrm{D}$ have produced similar outcomes for fracture $(102,103,104)$ and bone density (105, $106,107,108)$ to trials where these supplements were co-administered. Thus, the use of calcium with or without vitamin $\mathrm{D}$ by patients taking osteoporosis treatments is probably unnecessary. An important caveat is that administration of potent antiresorptive agents to frail elderly patients with marked vitamin D deficiency can provoke significant hypocalcemia, which can be prevented through a short course of vitamin D supplements.

\section{Current recommendations}

Numerous authoritative groups have made recent recommendations about the use of calcium with or without vitamin D. These recommendations range from recommendations against their use in primary fracture prevention (US Preventative Services Task Force) (109) through to daily intake of calcium of $1000-1200 \mathrm{mg}$ and vitamin D of up to $2000 \mathrm{IU}$ (see Table in 110). The reasons for the persistence of strong recommendations for the use of calcium and vitamin D when the available evidence does not support such recommendations are not clear. We hypothesized that strong links between industry

Table 2 Risk-benefit profile of calcium supplements in large $(N>1000)$ randomized placebo-controlled trials.

\begin{tabular}{|c|c|c|c|c|}
\hline \multirow[b]{2}{*}{ Trial } & \multirow[b]{2}{*}{ Treatment } & \multirow[b]{2}{*}{ Number of participants } & \multicolumn{2}{|c|}{ Benefit-risk profile } \\
\hline & & & Benefit $^{\mathrm{a}}$ & Harm $^{a}$ \\
\hline (60) & CaD & 3270 & $\begin{array}{l}-55 \text { All fracture } \\
-30 \text { Hip fracture }\end{array}$ & $\begin{array}{l}\text { +12 Gl symptoms } \\
+1 \text { Hypercalcaemia }\end{array}$ \\
\hline (54) & $\mathrm{Ca}$ or $\mathrm{CaD}$ & 5292 & -36 All fracture & $\begin{array}{l}\text { +7 Hip fracture } \\
+109 \text { Gl symptoms } \\
+16 \text { Myocardial infarction }\end{array}$ \\
\hline (31) & $\mathrm{CaD}$ & 36,282 & $\begin{array}{l}-54 \text { All fracture } \\
-14 \text { Hip fracture }\end{array}$ & $\begin{array}{l}\text { +261 Constipation } \\
\text { +68 Kidney stone } \\
\text { +177 Hypercalcaemia } \\
\text { +21 Myocardial infarctionb }\end{array}$ \\
\hline (34) & $\mathrm{Ca}$ & 1460 & -16 All fracture & $\begin{array}{l}+5 \text { Hip fracture } \\
+32 \text { Constipation } \\
+24 \text { GI hospitalization }\end{array}$ \\
\hline (55) & $\mathrm{Ca}$ & 1471 & $\begin{array}{l}-13 \text { All fracture } \\
-2 \text { Kidney stone }\end{array}$ & $\begin{array}{l}+12 \text { Hip fracture } \\
+50 \text { Constipation } \\
+10 \text { Myocardial infarction }\end{array}$ \\
\hline
\end{tabular}

${ }^{a}$ Number of cases in treatment group less number of cases in control group. Benefit: fewer cases in the treatment group; Harm more cases in treatment group. ${ }^{b}$ Data for entire cohort. There was an interaction between risk of myocardial infarction, CaD treatment and use of personal calcium supplements $(41,54)$. In women not taking personal calcium supplements, there were +41 myocardial infarctions in the CaD group; in women taking personal calcium, there were -16 myocardial infarctions in the CaD group.

Ca, calcium; CaD, calcium and vitamin D; Gl, gastrointestinal. 
and academics, specialist societies and advocacy groups involved in osteoporosis management might be a possible contributing factor (111).

\section{Conclusion}

Based on the results of the large RCTs of calcium with or without vitamin $\mathrm{D}$ with fracture as a primary outcome, it is reasonable to conclude that any benefit in preventing fractures is at best very small, if there is any at all, and that any such benefit is outweighed by the small risk of serious adverse events. This unfavorable risk-benefit profile is further weakened by the issues of poor long-term compliance, which is often related to mild but common gastrointestinal side effects. Faced with this information, taking these supplements is unlikely to be attractive to individuals. Furthermore, there is currently no consistent evidence of a relationship between dietary calcium intake and risk of fracture. This suggests that clinicians, advocacy organizations and health policymakers should not recommend an increase in dietary calcium or the use of calcium with or without vitamin D supplements for fracture prevention or when osteoporosis treatments are prescribed. Individuals at high risk of fracture should be offered treatments proven to prevent fracture that have a favorable risk-benefit profile.

\section{Declaration of interest}

The authors declare that there is no conflict of interest that could be perceived as prejudicing the impartiality of this debate.

\section{Funding}

This research did not receive any specific grant from any funding agency in the public, commercial or not-for-profit sector.

\section{References}

1 Hernlund E, Svedbom A, Ivergard M, Compston J, Cooper C, Stenmark J, McCloskey EV, Jonsson B \& Kanis JA. Osteoporosis in the European Union: medical management, epidemiology and economic burden: a report prepared in collaboration with the International Osteoporosis Foundation (IOF) and the European Federation of Pharmaceutical Industry Associations (EFPIA). Archives of Osteoporosis 20138 136. (https;//doi.org/10.1007/s11657-013-0136-1)

2 Harvey N, Dennison E \& Cooper C. Osteoporosis: impact on health and economics. Nature Reviews Rheumatology 20106 99-105. (https:// doi.org/10.1038/nrrheum.2009.260)

3 Fielding RA, Vellas B, Evans WJ, Bhasin S, Morley JE, Newman AB, Abellan van Kan G, Andrieu S, Bauer J, Breuille D et al. Sarcopenia: an undiagnosed condition in older adults. Current consensus definition: prevalence, etiology, and consequences. International working group. On sarcopenia. Journal of the American Medical Directors Association 201112 249-256. (https://doi.org/10.1016/j. jamda.2011.01.003)
4 Aloia J, Bojadzievski T, Yusupov E, Shahzad G, Pollack S, Mikhail M $\&$ Yeh J. The relative influence of calcium intake and vitamin D status on serum parathyroid hormone and bone turnover biomarkers in a double-blind, placebo-controlled parallel group, longitudinal factorial design. Journal of Clinical Endocrinology and Metabolism 2010 95 3216-3224. (https://doi.org/10.1210/jc.2009-1294)

5 Chung M, Lee J, Terasawa T, Lau J \& Trikalinos TA. Vitamin D with or without calcium supplementation for prevention of cancer and fractures: an updated meta-analysis for the U.S. preventive services task force. Annals of Internal Medicine 2011155 827-838. (https://doi. org/10.7326/0003-4819-155-12-201112200-00005)

6 Abrahamsen B. The calcium and vitamin D controversy. Therapeutic Advances in Musculoskeletal Disease 20179 107-114. (https://doi.org/1 $0.1177 / 1759720 X 16685547)$

7 Weaver CM, Alexander DD, Boushey CJ, Dawson-Hughes B, Lappe JM, LeBoff MS, Liu S, Looker AC, Wallace TC \& Wang DD. Calcium plus vitamin D supplementation and risk of fractures: an updated meta-analysis from the National Osteoporosis Foundation. Osteoporosis International 201627 367-376. (https://doi.org/10.1007/ s00198-015-3386-5)

8 Kanis JA, Cooper C, Rizzoli R, Abrahamsen B, Al-Daghri NM, Brandi ML, Cannata-Andia J, Cortet B, Dimai HP, Ferrari S et al. Identification and management of patients at increased risk of osteoporotic fracture: outcomes of an ESCEO expert consensus meeting. Osteoporosis International 201728 2023-2034. (https://doi. org/10.1007/s00198-017-4009-0)

9 Bolland MJ, Grey A, Avenell A, Gamble GD \& Reid IR. Calcium supplements with or without vitamin D and risk of cardiovascular events: reanalysis of the Women's Health Initiative limited access dataset and meta-analysis. BMJ 2011342 d2040. (https://doi. org/10.1136/bmj.d2040)

10 Bolland MJ, Avenell A, Baron JA, Grey A, Maclennan GS, Gamble GD $\&$ Reid IR. Effect of calcium supplements on risk of myocardial infarction and cardiovascular events: meta-analysis. BMJ 2010341 c3691. (https://doi.org/10.1136/bmj.c3691)

11 Abrahamsen B \& Sahota O. Do calcium plus vitamin D supplements increase cardiovascular risk? BMJ 2011342 d2080. (https://doi. org/10.1136/bmj.d2080)

12 Blau JE \& Collins MT. The PTH-Vitamin D-FGF23 axis. Reviews in Endocrine and Metabolic Disorders 201516 165-174. (https://doi. org/10.1007/s11154-015-9318-z)

13 Seeman E. Structural basis of growth-related gain and age-related loss of bone strength. Rheumatology 200847 iv2-iv8. (https://doi. org/10.1093/rheumatology/ken265)

14 Rozenberg S, Body JJ, Bruyère O, Bergmann P, Brandi ML, Cooper C, Devogelaer JP, Gielen E, Goemaere S, Kaufman JM et al. Effects of dairy products consumption on health: benefits and beliefs-A commentary from the Belgian Bone Club and the European Society for clinical and economic aspects of osteoporosis, osteoarthritis and musculoskeletal diseases. Calcified Tissue International 201698 1-17. (https://doi.org/10.1007/s00223-015-0062-x)

15 Ethgen O, Hiligsmann M, Burlet N \& Reginster JY. Costeffectiveness of personalized supplementation with vitamin D-rich dairy products in the prevention of osteoporotic fractures. Osteoporosis International 201627 301-308. (https://doi. org/10.1007/s00198-015-3319-3)

16 Mirza F \& Canalis E. Secondary osteoporosis: pathophysiology and management. European Journal of Endocrinology 2015173 R131-R151. (https://doi.org/10.1530/EJE-15-0118)

17 Heaney RP. Vitamin D and calcium interactions: functional outcomes. American Journal of Clinical Nutrition 200888 541S-544S.

18 Kuo IY \& Ehrlich BE. Signaling in muscle contraction. Cold Spring Harbor perspectives in Biology 20157 a006023. (https://doi. org/10.1101/cshperspect.a006023)

19 Gehlert S, Bloch W \& Suhr F. Ca2+-dependent regulations and signaling in skeletal muscle: from electro-mechanical coupling 
to adaptation. International Journal of Molecular Sciences 201516 1066-1095. (https://doi.org/10.3390/ijms16011066)

20 Cano A, Chedraui P, Goulis DG, Lopes P, Mishra G, Mueck A, Senturk LM, Simoncini T, Stevenson JC, Stute P et al. Calcium in the prevention of postmenopausal osteoporosis: EMAS clinical guide. Maturitas 2018107 7-12. (https://doi.org/10.1016/j. maturitas.2017.10.004)

21 Bailey RL, Dodd KW, Goldman JA, Gahche JJ, Dwyer JT, Moshfegh AJ, Sempos CT \& Picciano MF. Estimation of total usual calcium and vitamin D intakes in the United States. Journal of Nutrition 2010140 817-822. (https://doi.org/10.3945/jn.109.118539)

22 Eller-Vainicher C, Chiodini I, Santi I, Massarotti M, Pietrogrande L, Cairoli E, Beck-Peccoz P, Longhi M, Galmarini V, Gandolini G et al. Recognition of morphometric vertebral fractures by artificial neural networks: analysis from GISMO Lombardia Database. PLoS ONE 2011 6 e27277. (https://doi.org/10.1371/journal.pone.0027277)

23 Giorgini M, Vitale M, Bozzetto L, Ciano O, Giacco A, Rivieccio A, Calabrese I, Riccardi G, Rivellese AA \& Annuzzi G. Micronutrient intake in a cohort of Italian adults with type 1 diabetes: adherence to dietary recommendations. Journal of Diabetes Research 20172017 2682319.

24 Reid IR, Ames R, Mason B, Reid HE, Bacon CJ, Bolland MJ, Gamble GD, Grey A \& Horne A. Randomized controlled trial of calcium supplementation in healthy, nonosteoporotic, older men. Archives of Internal Medicine 2008168 2276-2282. (https://doi. org/10.1001/archinte.168.20.2276)

25 Bristow SM, Gamble GD, Horne AM \& Reid IR. Dietary calcium intake and rate of bone loss in men. British Journal of Nutrition 2017 117 1432-1438. (https://doi.org/10.1017/S0007114517001301)

26 National Institutes of Health. (available at: https://ods.od.nih.gov/ factsheets/Calcium-HealthProfessional/). Accessed on 17 September 2017.

27 https://nos.org.uk/information/healthy-living-and-risk/healthyeating-for-strongbones/. Accessed on 17 September 2017.

28 Lima GA, Lima PD, Barros Mda G, Vardiero LP, Melo EF, ParanhosNeto Fde P, Madeira M \& Farias ML. Calcium intake: good for the bones but bad for the heart? An analysis of clinical studies. Archives of Endocrinology and Metabolism 20163 252-263. (https://doi. org/10.1590/2359-3997000000173)

29 Zhang ZQ, Ma XM, Huang ZW, Yang XG, Chen YM \& Su YX. Effects of milk salt supplementation on bone mineral gain in pubertal Chinese adolescents: a 2-year randomized, double-blind, controlled, dose-response trial. Bone 201465 69-76. (https://doi.org/10.1016/j. bone.2014.05.007)

30 Kalkwarf HJ, Khoury JC \& Lanphear BP. Milk intake during childhood and adolescence, adult bone density, and osteoporotic fractures in US women. American Journal of Clinical Nutrition $2003 \mathbf{7 7}$ 257-265. (https://doi.org/10.1093/ajcn/77.1.257)

31 Jackson RD, Lacroix AZ, Gass M, Wallace RB, Robbins J, Lewis CE, Bassford T, Beresford SA, Black HR, Blanchette P et al. Calcium plus vitamin D supplementation and the risk of fractures. New England Journal of Medicine 2006354 669-683. (https://doi.org/10.1056/ NEJMoa055218)

32 Kim KM, Choi SH, Lim S, Moon JH, Kim JH, Kim SW, Jang HC $\&$ Shin CS. Interactions between dietary calcium intake and bone mineral density or bone geometry in a low calcium intake population (KNHANES IV 2008-2010). Journal of Clinical Endocrinology and Metabolism 201499 2409-2417. (https://doi. org/10.1210/jc.2014-1006)

33 Shea B, Wells G, Cranney A, Zytaruk N, Robinson V, Griffith L, Ortiz Z, Peterson J, Adachi J, Tugwell P et al. Meta-analyses of therapies for postmenopausal osteoporosis. VII. Meta-analysis of calcium supplementation for the prevention of postmenopausal osteoporosis. Endocrine Reviews 200223 552-559. (https://doi. org/10.1210/er.2001-7002)
34 Prince RL, Devine A, Dhaliwal SS \& Dick IM. Effects of calcium supplementation on clinical fracture and bone structure: results of a 5-year, double-blind, placebo-controlled trial in elderly women. Archives of Internal Medicine 2006166 869-875. (https://doi. org/10.1001/archinte.166.8.869)

35 Silk LN, Greene DA \& Baker MK. The effect of calcium or calcium and vitamin D supplementation on bone mineral density in healthy males: a systematic review and meta-analysis. International Journal of Sport Nutrition and Exercise Metabolism 201525 510-524. (https://doi. org/10.1123/ijsnem.2014-0202)

36 Tai V, Leung W, Grey A, Reid IR \& Bolland MJ. Calcium intake and bone mineral density: systematic review and meta-analysis. BMJ 2015 351 h4183. (https://doi.org/10.1136/bmj.h4183)

37 Bischoff-Ferrari HA, Dawson-Hughes B, Staehelin HB, Orav JE, Stuck AE, Theiler R, Wong JB, Egli A, Kiel DP \& Henschkowski J. Fall prevention with supplemental and active forms of vitamin D: a meta-analysis of randomised controlled trials. BMJ 2009339 b3692. (https://doi.org/10.1136/bmj.b3692)

38 Murad MH, Elamin KB, Abu Elnour NO, Elamin MB, Alkatib AA, Fatourechi MM, Almandoz JP, Mullan RJ, Lane MA, Liu H et al. Clinical review: the effect of vitamin D on falls: a systematic review and meta-analysis. Journal of Clinical Endocrinology and Metabolism 201196 2997-3006. (https://doi.org/10.1210/jc.2011-1193)

39 Beaudart C, Buckinx F, Rabenda V, Gillain S, Cavalier E, Slomian J, Petermans J, Reginster JY \& Bruyere O. The effects of vitamin D on skeletal muscle strength, muscle mass, and muscle power: a systematic review and meta-analysis of randomized controlled trials. Journal of Clinical Endocrinology and Metabolism 201499 4336-4345. (https://doi.org/10.1210/jc.2014-1742)

40 LeBlanc ES \& Chou R. VItamin D and falls - fitting new data with current guidelines. JAMA Internal Medicine 2015175 712-713. (https://doi.org/10.1001/jamainternmed.2015.0248)

41 Cameron ID, Gillespie LD, Robertson MC, Murray GR, Hill KD, Cumming RG \& Kerse N. Interventions for preventing falls in older people in care facilities and hospitals. Cochrane Database of Systematic Reviews 201212 CD005465.

42 Bolland MJ, Grey A, Gamble GD \& Reid IR. The effect of vitamin D supplementation on skeletal, vascular, or cancer outcomes: a trial sequential meta-analysis. Lancet Diabetes and Endocrinology 20142 307-320. (https://doi.org/10.1016/S2213-8587(13)70212-2)

43 Dukas L, Bischoff HA, Lindpaintner LS, Schacht E, Birkner-Binder D, Damm TN, Thalmann B \& Stahelin HB. Alfacalcidol reduces the number of fallers in a community-dwelling elderly population with a minimum calcium intake of more than $500 \mathrm{mg}$ daily. Journal of the American Geriatrics Society 200452 230-236. (https://doi.org/10.1111/ j.1532-5415.2004.52060.x)

44 Bischoff-Ferrari HA, Dawson-Hughes B, Willett WC, Staehelin HB, Bazemore MG, Zee RY \& Wong JB. Effect of vitamin D on falls: a meta-analysis. JAMA 2004291 1999-2006. (https://doi.org/10.1001/ jama.291.16.1999)

45 Michael YL, Whitlock EP, Lin JS, Fu R \& O'Connor EA \& Gold R. Primary care-relevant interventions to prevent falling in older adults: a systematic evidence review for the U.S. Preventive Services Task Force. Annals of Internal Medicine 2010153 815-825. (https://doi. org/10.7326/0003-4819-153-12-201012210-00008)

46 Kalyani RR, Stein B, Valiyil R, Manno R, Maynard JW \& Crews DC. Vitamin $\mathrm{D}$ treatment for the prevention of falls in older adults: systematic review and meta-analysis. Journal of the American Geriatrics Society 201058 1299-1310. (https://doi.org/10.1111/j.15325415.2010.02949.x)

47 Seo MH, Kim MK, Park SE, Rhee EJ, Park CY, Lee WY, Baek KH, Song KH, Kang MI \& Oh KW. The association between daily calcium intake and sarcopenia in older, non-obese Korean adults: the fourth Korea National Health and Nutrition Examination Survey (KNHANES IV) 2009. Endocrine Journal $201360679 \mathrm{e} 686$. 
48 Brotto M. Aging, sarcopenia and store-operated calcium entry: a common link? Cell Cycle $2011 \mathbf{1 0} 4201 \mathrm{e} 4202$.

49 Fleet JC \& Schoch RD. Molecular mechanisms for regulation of intestinal calcium absorption by vitamin $\mathrm{D}$ and other factors. Critical Reviews in Clinical Laboratory Sciences 201047 181e195. (https://doi. org/10.3109/10408363.2010.536429)

50 Tang BM, Eslick GD, Nowson C, Smith C \& Bensoussan A. Use of calcium or calcium in combination with vitamin $\mathrm{D}$ supplementation to prevent fractures and bone loss in people aged 50 years and older: a meta-analysis. Lancet 2007370 657-666. (https://doi.org/10.1016/ S0140-6736(07)61342-7)

51 Bischoff-Ferrari HA, Dawson-Hughes B, Baron JA, Burckhardt P, Li R, Spiegelman D, Specker B, Orav JE, Wong JB, Staehelin HB et al. Calcium intake and hip fracture risk in men and women: a meta-analysis of prospective cohort studies and randomized controlled trials. American Journal of Clinical Nutrition 200786 1780-1790.

52 Bolland MJ, Leung W, Tai V, Bastin S, Gamble GD, Grey A \& Reid IR. Calcium intake and risk of fracture: systematic review. BMJ 2015351 h4580. (https://doi.org/10.1136/bmj.h4580)

53 Group DVDIPAoRT. Patient level pooled analysis of 68500 patients from seven major vitamin D fracture trials in US and Europe. BMJ 2010340 b5463.

54 Grant AM, Avenell A, Campbell MK, Mcdonald AM, Maclennan GS, Mcpherson GC, Anderson FH, Cooper C, Francis RM, Donaldson C et al. Oral vitamin D3 and calcium for secondary prevention of low-trauma fractures in elderly people (Randomised Evaluation of Calcium Or vitamin D, RECORD): a randomised placebo-controlled trial. Lancet 2005365 1621-1628. (https://doi.org/10.1016/S01406736(05)63013-9)

55 Reid IR, Mason B, Horne A, Ames R, Reid HE, Bava U, Bolland MJ \& Gamble GD. Randomized controlled trial of calcium in healthy older women. American Journal of Medicine 2006119 777-785. (https://doi. org/10.1016/j.amjmed.2006.02.038)

56 Weaver CM, Dawson-Hughes B, Lappe JM \& Wallace TC. Re: errors in the NOF meta-analysis of calcium and vitamin D supplements. Osteoporosis International 201627 2641-2642. (https://doi. org/10.1007/s00198-016-3525-7)

57 Weaver CM, Dawson-Hughes B, Lappe JM \& Wallace TC. Erratum and additional analyses re: calcium plus vitamin $\mathrm{D}$ supplementation and the risk of fractures: an updated meta-analysis from the National Osteoporosis Foundation Osteoporosis International 201627 2643-2646. (https://doi.org/10.1007/s00198-016-3699-z)

58 Prentice RL, Pettinger MB, Jackson RD, Wactawski-Wende J, Lacroix AZ, Anderson GL, Chlebowski RT, Manson JE, Van Horn L, Vitolins MZ et al. Health risks and benefits from calcium and vitamin D supplementation: Women's Health Initiative clinical trial and cohort study. Osteoporosis International 201324 567-580. (https://doi. org/10.1007/s00198-012-2224-2)

59 Blumberg J, Heaney RP, Huncharek M, Scholl T, Stampfer M, Vieth R, Weaver CM \& Zeisel SH. Evidence-based criteria in the nutritional context. Nutrition Reviews 201068 478-484. (https://doi.org/10.1111/ j.1753-4887.2010.00307.x)

60 Chapuy MC, Arlot ME, Duboeuf F, Brun J, Crouzet B, Arnaud S, Delmas PD \& Meunier PJ. Vitamin D3 and calcium to prevent hip fractures in the elderly women. New England Journal of Medicine 1992 327 1637-1642. (https://doi.org/10.1056/NEJM199212033272305)

61 Lips P, Bouillon R, van Schoor NM, Vanderschueren D, Verschueren S, Kuchuk N, Milisen K \& Boonen S. Reducing fracture risk with calcium and vitamin D. Clinical Endocrinology 201073 277-285. (https://doi.org/10.1111/j.1365-2265.2009.03701.x)

62 Zhao JG, Zeng XT, Wang J \& Liu L. Association between calcium or vitamin $\mathrm{D}$ supplementation and fracture incidence in communitydwelling older adults: a systematic review and meta-analysis. JAMA 2017318 2466-2482. (https://doi.org/10.1001/jama.2017.19344)
63 Holick MF, Binkley NC, Bischoff-Ferrari HA, Gordon CM, Hanley DA, Heaney RP, Murad MH \& Weaver CM \& Endocrine Society. Evaluation, treatment, and prevention of vitamin D deficiency: an Endocrine Society clinical practice guideline. Journal of Clinical Endocrinology and Metabolism 201196 1911-1930. (https://doi. org/10.1210/jc.2011-0385)

64 Compston J, Cooper A, Cooper C, Gittoes N, Gregson C, Harvey N, Hope S, Kanis JA, McCloskey EV, Poole KES et al. UK clinical guideline for the prevention and treatment of osteoporosis. Archives of Osteoporosis 201712 43. (https://doi.org/10.1007/s11657-0170324-5)

65 Curtis EM, Moon RJ, Dennison EM, Harvey NC \& Cooper C. Recent advances in the pathogenesis and treatment of osteoporosis. Clinical Medicine 201515 (Supplement 6) s92-s96. (https://doi.org/10.7861/ clinmedicine.15-6-s92)

66 Adami S, Isaia G, Luisetto G, Minisola S, Sinigaglia L, Gentilella R, Agnusdei D, Iori N, Nuti R \& ICARO Study Group. Fracture incidence and characterization in patients on osteoporosis treatment: the ICARO study. Journal of Bone and Mineral Research 200621 1565-1570. (https://doi.org/10.1359/jbmr.060715)

67 Varenna M, Binelli L, Zucchi F, Ghiringhelli D \& Sinigaglia L. Unbalanced diet to lower serum cholesterol level is a risk factor for postmenopausal osteoporosis and distal forearm fracture. Osteoporosis International 200112 296-301. (https://doi.org/10.1007/ s001980170119)

68 Carnevale V, Modoni S, Pileri M, Di Giorgio A, Chiodini I, Minisola S, Vieth R \& Scillitani A. Longitudinal evaluation of vitamin D status in healthy subjects from southern Italy: seasonal and gender differences. Osteoporosis International 200112 1026-1030. (https:// doi.org/10.1007/s001980170012)

69 Hanwell HE, Vieth R, Cole DE, Scillitani A, Modoni S, Frusciante V, Ritrovato G, Chiodini I, Minisola S \& Carnevale V. Sun exposure questionnaire predicts circulating 25-hydroxyvitamin D concentrations in Caucasian hospital workers in southern Italy. Journal of Steroid Biochemistry and Molecular Biology 2010121 334-337. (https://doi.org/10.1016/j.jsbmb.2010.03.023)

70 Ursoniu S, Mikhailidis DP, Serban MC, Penson P, Toth PP, Ridker PM, Ray KK, Kees Hovingh G, Kastelein JJ, Hernandez AV et al. The effect of statins on cardiovascular outcomes by smoking status: a systematic review and meta-analysis of randomized controlled trials. Pharmacological Research 2017122 105-117. (https://doi. org/10.1016/j.phrs.2017.06.002)

71 Boonen S, Bischoff-Ferrari HA, Cooper C, Lips P, Ljunggren O, Meunier PJ \& Reginster JY. Addressing the musculoskeletal components of fracture risk with calcium and vitamin D: a review of the evidence. Calcified Tissue International 200678 257-270. (https:// doi.org/10.1007/s00223-005-0009-8)

72 Anderson JJ, Roggenkamp KJ \& Suchindran CM. Calcium intakes and femoral and lumbar bone density of elderly U.S. men and women: National Health and Nutrition Examination Survey 2005-2006 analysis. Journal of Clinical Endocrinology and Metabolism 201297 4531-4539. (https://doi.org/10.1210/jc.2012-1407)

73 Castro-Lionard K, Dargent-Molina P, Fermanian C, Gonthier R \& Cassou B. Use of calcium supplements, vitamin D supplements and specific osteoporosis drugs among French women aged 75-85 years: patterns of use and associated factors. Drugs Aging $2013 \mathbf{3 0}$ 1029-1038. (https://doi.org/10.1007/s40266-013-0121-9)

74 Xiao Q, Murphy RA, Houston DK, Harris TB, Chow WH \& Park Y. Dietary and supplemental calcium intake and cardiovascular disease mortality: the National Institutes of Health-AARP Diet and Health Study. JAMA Internal Medicine 2013173 639-646. (https://doi. org/10.1001/jamainternmed.2013.3283)

75 Albright F, Smith PH \& Richardson AM. Postmenopausal osteoporosis - Its clinical features. JAMA 1941116 2465-2474. (https://doi. org/10.1001/jama.1941.02820220007002) 
76 Reifenstein EC Jr\& Albright F. The metabolic effects of steroid hormones in osteoporosis. Journal of Clinical Investigation 194726 24-56. (https://doi.org/10.1172/JCI101787)

77 Nicholls L \& Nimalasuriya A. Adaptation to a low calcium intake in reference to the calcium requirements of a tropical population. Journal of Nutrition 193918 563-577. (https://doi.org/10.1093/ jn/18.6.563)

78 Hegsted DM, Moscoso I \& Collazos C. A study of the minimum calcium requirements of adult men. Journal of Nutrition $1952 \mathbf{4 6}$ 181-201. (https://doi.org/10.1093/jn/46.2.181)

79 Walker ARP. Some aspects of nutritional research in SouthAfrica. Nutrition Reviews 195614 321-324. (https://doi. org/10.1111/j.1753-4887.1956.tb01441.x)

80 Pathak CL. Nutritional adaptation to low dietary intakes of calories, proteins, vitamins, and minerals in the tropics. American Journal of Clinical Nutrition 19586 151-158. (https://doi.org/10.1093/ ajcn/6.2.151)

81 Anonymous. Recommended dietary allowances, 1953. Nutrition Reviews 195412 240-242.

82 Food and Agriculture Organisation of the United Nations \& World Health Organisation. Handbook on Human Nutritional Requirements. Geneva: World Health Organisation, 1974.

83 Heaney RP, Recker RR \& Saville PD. Calcium balance and calcium requirements in middle-aged women. American Journal of Clinical Nutrition 197730 1603-1611. (https://doi.org/10.1093/ ajcn/30.10.1603)

84 Heaney RP, Recker RR \& Saville PD. Menopausal changes in calcium balance performance. Journal of Laboratory and Clinical Medicine 1978 92 953-963.

85 Dawson-Hughes B, Dallal GE, Krall EA, Sadowski L, Sahyoun N $\&$ Tannenbaum S. A controlled trial of the effect of calcium supplementation on bone density in postmenopausal women. New England Journal of Medicine 1990323 878-883. (https://doi. org/10.1056/NEJM199009273231305)

86 Dawson-Hughes B, Harris SS, Krall EA \& Dallal GE. Effect of calcium and vitamin $\mathrm{D}$ supplementation on bone density in men and women 65 years of age or older. New England Journal of Medicine 1997337 670-676. (https://doi.org/10.1056/NEJM199709043371003)

87 Kanis JA \& Passmore R. Calcium supplementation of the diet - I. BMJ 1989298 137-140. (https://doi.org/10.1136/ bmj.298.6667.137)

88 Kanis JA \& Passmore R. Calcium supplementation of the diet - II. BMJ 1989298 205-208. (https://doi.org/10.1136/bmj.298.6668.205)

89 Hunt CD \& Johnson LK. Calcium requirements: new estimations for men and women by cross-sectional statistical analyses of calcium balance data from metabolic studies. American Journal of Clinical Nutrition 200786 1054-1063.

90 Nilas L, Christiansen C \& Rodbro P. Calcium supplementation and postmenopausal bone loss. BMJ 1984289 1103-1106. (https://doi. org/10.1136/bmj.289.6452.1103)

91 Porthouse J, Cockayne S, King C, Saxon L, Steele E, Aspray T, Baverstock M, Birks Y, Dumville J, Francis R et al. Randomised controlled trial of calcium and supplementation with cholecalciferol (vitamin D3) for prevention of fractures in primary care. BMJ 2005 330 1003. (https://doi.org/10.1136/bmj.330.7498.1003)

92 Salovaara K, Tuppurainen M, Karkkainen M, Rikkonen T, Sandini L, Sirola J, Honkanen R, Alhava E \& Kroger H. Effect of vitamin $\mathrm{D}(3)$ and calcium on fracture risk in 65- to 71-year-old women: a population-based 3-year randomized, controlled trial--the OSTPREFPS. Journal of Bone and Mineral Research 201025 1487-1495. (https:// doi.org/10.1002/jbmr.48)

93 Bolland MJ \& Grey A. A case study of discordant overlapping metaanalyses: vitamin D supplements and fracture. PLOS ONE 20149 e115934. (https://doi.org/10.1371/journal.pone.0115934)

94 Avenell A, Mak JC \& O'Connell D. Vitamin D and vitamin D analogues for preventing fractures in post-menopausal women and older men. Cochrane Database of Systematic Reviews 20144 CD000227.

95 Chapuy MC, Pamphile R, Paris E, Kempf C, Schlichting M, Arnaud S, Garnero P \& Meunier PJ. Combined calcium and vitamin D3 supplementation in elderly women: confirmation of reversal of secondary hyperparathyroidism and hip fracture risk: the Decalyos II study. Osteoporosis International 200213 257-264. (https://doi. org/10.1007/s001980200023)

96 Lewis JR, Zhu K \& Prince RL. Adverse events from calcium supplementation: relationship to errors in myocardial infarction self-reporting in randomized controlled trials of calcium supplementation. Journal of Bone and Mineral Research 201227 719-722. (https://doi.org/10.1002/jbmr.1484)

97 Bolland MJ, Barber PA, Doughty RN, Mason B, Horne A, Ames R, Gamble GD, Grey A \& Reid IR. Vascular events in healthy older women receiving calcium supplementation: randomised controlled trial. BMJ 2008336 262-266. (https://doi.org/10.1136/ bmj.39440.525752.BE)

98 Reid IR, Bolland MJ \& Grey A. Effect of calcium supplementation on hip fractures. Osteoporosis International 200819 1119-1123. (https:// doi.org/10.1007/s00198-008-0563-9)

99 Prentice RL, Jackson RD, Pettinger M \& Rossouw JE. Incidence of milk alkali syndrome in the Women's Health Initiative clinical trial and cohort study: response to Neupane. Osteoporosis International 201425 1195. (https://doi.org/10.1007/s00198-013-2461-z)

100 Gallagher JC, Smith LM \& Yalamanchili V. Incidence of hypercalciuria and hypercalcemia during vitamin $\mathrm{D}$ and calcium supplementation in older women. Menopause 201421 1173-1180. (https://doi.org/10.1097/GME.0000000000000270)

101 Bolland MJ, Grey A \& Reid IR. Should we prescribe calcium or vitamin D supplements to treat or prevent osteoporosis? Climacteric 201518 (Supplement 2) 22-31. (https://doi.org/10.3109/13697137.2 015.1098266)

102 Rossouw JE, Anderson GL, Prentice RL, Lacroix AZ, Kooperberg C, Stefanick ML, Jackson RD, Beresford SA, Howard BV, Johnson KC et al. Risks and benefits of estrogen plus progestin in healthy postmenopausal women: principal results From the Women's Health Initiative randomized controlled trial. JAMA 2002288 321-333. (https://doi.org/10.1001/jama.288.3.321)

103 Anderson GL, Limacher M, Assaf AR, Bassford T, Beresford SA, Black H, Bonds D, Brunner R, Brzyski R, Caan B et al. Effects of conjugated equine estrogen in postmenopausal women with hysterectomy: the Women's Health Initiative randomized controlled trial. JAMA 2004291 1701-1712. (https://doi.org/10.1001/ jama.291.14.1701)

104 Mccloskey EV, Beneton M, Charlesworth D, Kayan K, Detakats D, Dey A, Orgee J, Ashford R, Forster M, Cliffe J et al. Clodronate reduces the incidence of fractures in community-dwelling elderly women unselected for osteoporosis: results of a doubleblind, placebo-controlled randomized study. Journal of Bone and Mineral Research 200722 135-141. (https://doi.org/10.1359/ jbmr.061008)

105 Hosking D, Chilvers CE, Christiansen C, Ravn P, Wasnich R, Ross P, Mcclung M, Balske A, Thompson D, Daley M et al. Prevention of bone loss with alendronate in postmenopausal women under 60 years of age. Early Postmenopausal Intervention Cohort Study Group. New England Journal of Medicine 1998338 485-492. (https://doi.org/10.1056/ NEJM199802193380801)

106 Black DM, Delmas PD, Eastell R, Reid IR, Boonen S, Cauley JA, Cosman F, Lakatos P, Leung PC, Man Z et al. Once-yearly zoledronic acid for treatment of postmenopausal osteoporosis. New England Journal of Medicine 2007356 1809-1822. (https://doi.org/10.1056/ NEJMoa067312)

107 Bonnick S, Broy S, Kaiser F, Teutsch C, Rosenberg E, Delucca P \& Melton M. Treatment with alendronate plus calcium, alendronate 
alone, or calcium alone for postmenopausal low bone mineral density. Current Medical Research and Opinion 200723 1341-1349. (https://doi.org/10.1185/030079907X188035)

108 Mcclung M, Miller P, Recknor C, Mesenbrink P, Bucci-Rechtweg C $\&$ Benhamou CL. Zoledronic acid for the prevention of bone loss in postmenopausal women with low bone mass: a randomized controlled trial. Obstetrics and Gynecology 2009 114 999-1007. (https://doi.org/10.1097/AOG.0b013e3181bdce0a)

109 Moyer VA. Vitamin D and calcium supplementation to prevent fractures in adults: U.S. preventive services task force recommendation statement. Annals of Internal Medicine 2013158 691-696.

110 Grey A \& Bolland M. Web of industry, advocacy, and academia in the management of osteoporosis. BMJ 2015351 h3170. (https://doi. org/10.1136/bmj.h3170)

111 Hsia J, Heiss G, Ren H, Allison M, Dolan NC, Greenland P, Heckbert SR, Johnson KC, Manson JE, Sidney S et al. Calcium/ vitamin D supplementation and cardiovascular events. Circulation 2007115 846-854. (https://doi.org/10.1161/ CIRCULATIONAHA.106.673491)

Received 7 February 2018

Accepted 12 February 2018 